\title{
УДК: 613.6+616-006+691.32:001.5
}

\section{АНАЛИВ КАНШЕРОГЕННОЙ ОПАСНОСТИ М АСБЕСТОНЕМЕНТНЫХ ПРОИВВОАСТВАХ (АНАЛИТИЧЕСКОЕ ИССАЕАОВАНИЕ С ИСПОАЬЭОВАНИЕМ МЕТА-АНААИВА]}

\section{Варивончик А.В.}

\author{
Институт медишины труда АМН Украины, г. Киев
}

Провсдснным исследованисм установлсно, что широкос использованис асбестоцсмснтных изделий (кровельного материала и труб) в Украине обусловлсно их низкой ценой и наличием полсзных техничсских характеристик, отличающих их от аналогичных издслий, произвсдснных из альтсрнативных матсриалов. Риск возникновсния злокачественных новообразований среди работников асбестоцсмснтных производств формируется за счет волокон асбсста и кристалличсского кремния $\left(\mathrm{SiO}_{2}\right)$, содсржащсгося в цсмснтс. Основными мсханизмами нсопластичсской трансформации клсток органов-мишснсй под дсйствисм врсдных производствснных факторов являются: Fе ${ }^{2+}-$ и фагоцитозависимый «оксидантный стресс» (вызванный волокнами асбеста длиной >10 мкм, кристаллами $\mathrm{SiO}_{2}-$ кварц, кристобалит); прямос поврсждснис генома клсток (волокнами асбеста длиной < 10 мкм); цитокинозависимая пролифсрация клеток органов-мишсней (вызванная кристаллами $\mathrm{SiO}_{2}$ ).

Провсдснным кумулятивным мста-анализом 14 рстроспективных когортных исследований смертности работников асбестоцементного производства за период 1986-2004 годов в Великобритании, США, Швеции, Дании, Италии, России, Польшс, Литвс установлено повышснис относитсльного риска смсрти от злокачсствснных новообразований $(\mathrm{RR}=1,94)$ : без учста вида асбсста - плсвры $(\mathrm{RR}=5,37)$, лсгких $(\mathrm{RR}=1,75)$, толстой и прямой кишки $(R R=1,51)$, желудка $(R R=1,22)$, гортани $(R R=1,01)$. Повышсн риск смсртности в зазисимости от экспозиции работников разными видами асбеста: хризотил-асбест - общая смсртность $(R R=1,23)$, плевры $(R R=2,90)$, poтоглотки $(R R=1,83)$, гортани $(R R=1,16)$, толстой и прямой кишки $(R R=1,16)$; хрнзотил/крокидолит/амозит-асбст обшая смсртность $(R R=1,94)$, плевры $(R R=4,93)$, лсгких $(R R=2,06)$, толстой и прямой кишки $(R R=1,83)$, жслудка $(R R=1,31)$, гортани $(R R=1,11)$. Сдслан вывод о меньшсй канцсрогенной опасности при использовании в асбестоцсментном производстве хризотил-асбеста. Рскомсндовано продолжить эпидсмиологичсскис исслсдования, направлснныс на анализ рисков, вызванных комбинированным воздсйствисм хризотил-асбсста (различного химического состава), кристаллическим $\mathrm{SiO}_{2}$ (содержашимся в цементе) и другими химическими факторами (красителями и др.).

Ключевые слова: асбестоцементное производтво, канцерогенная опасность, асбест, двуокись кремния, относительный риск, смертность от злокачественных новообразований, мета-анализ

\section{Вступление}

Асбест - это группа природпых тонковолокпистых силнкатов различпой хнмической структуры, являщщнхся продуктами магматнческой крнсталлизацин. По хнмическому составу асбесты дслят на сергентины $\left[(\mathrm{R})_{3} \mathrm{Si}_{2} \mathrm{O}_{5}(\mathrm{OH})_{4}\right.$, где $\mathrm{R}-\mathrm{Mg}$, Fel (антигорит, хризотил, лизадmит) и амфнболль $\left[\mathrm{R}_{7}\left[\mathrm{Si}_{4} \mathrm{O}_{11}\right]_{2}(\mathrm{OH})_{2}\right.$, где $\mathrm{R}-\mathrm{Ca}, \mathrm{Mg}, \mathrm{Fe}$ (актинолит, амозит, антофиллить, крокидолит, тремолит и др.). Асбест также содержит в своем составе псбольшне количества тяжелых металлов - хрома, пикеля, маргапца и кобальта $[1,7,16-19]$.

Асбест является пениым промышленыbы материалом и входит в состав болес 3 тыс. изделий, нз пего изготавливают фнльтры, брезспты, зашитпые костюмы для ножариьх, бумагу, картол, стро- нтсльныс матерналы, тормозшые колодки для автомобнлей н т.д. Нанбольнсй экспозицни асбестами подвержены работиики и стронтельстве и судостроспин, на́ железподорожном грапснорте, в горной громышлспности, текстильном пронзводствс, при проведснин нзоляционшых работ и др. [16-19, 21, 32, 41]. Гланиыми потребителями асбеста являотся предприятня асбестопементиоӥ промышлешиости (70\% всего добывасмого асбеста), вынускающие прснмущественио стронтельиые матерналы (асбестоцемсптыьй нифер и труби) $[1,2,11,14]$.

Международнос агелтство по нзучению рака BO3 (International Agency on Research of Cancer IACR) относит асбест (актинолит, амозит, антофнллит, хрнзотнл, крокидолит, трнмолит) к I группе венцеств с доказаниой канцерогениостьо дыя 'е- 
ловека. Суицествует больщос число даных, получслшы в разиых странах, о связи професснональной экспознции асбестом и его смесями (ирн нигаляционлом путн поступлепня в организм человека) с увсличенисм заболевасмости раком легкнх и мезотелиомой париетальной плевры и брошишы. Это обуслоннло ограниснис и, в ряде стран, - запрет на использование асбеста в промыншеноости [ 10 , $16-19,21,32,41]$.

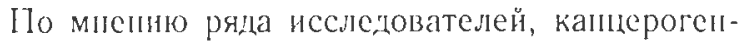
пая опасность асбеста пеодинакова н опредсляется сго видом (химичсским составом). Ряд авторов сиитает нанменее онасиым для человека хрнзотнласбсст, что обусловливаст возможность сго использования в промынленностн с мннималышым риском для здоровья работаюшцх. Прн этом существуют разиогласня относительно канщерогенПой опасности различиых асбестов, ис позволяюшие исследователям различпых страп достиглуть колсенсуса мнепий. Так, за полиый запрет добычи н нспользования всех вн,Һо асбеста выступают Европсйский союз, Чили, в противовес им Укранпа, Қанада, Қнргизня, Иран, Индня, Россня, Знмбабве, Перу, Илдопсзня и Ирак высказываются за щальнейнее нспользование в промышлсниости хрнзотнл-асбсста как самого бсзопаслого цля человека внда асбеста. LҺо 2008 года хрнзотнл-асбсст оетапется невнесениым в спнсок Роттсрдамской Копвенции (прнложспне №3) особо опасных вецеств, межлународиая торговля которыми запperuena $[7,10,41]$.

Большая промынленио-экономическая роль асбсста и палнчие пауниых разпогласнй относительно сго канцерогеной опасности цля человска обусловливают актуалыость проведсння нсследования,

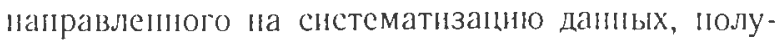
чеппых разлнчиыми нсследоватслями ция оценки сго опасностн дыя здоровья работаюцих. Учнтывая отсутствн лобычи н обоганения асбеста па террн торин Украниы н его преимуществениос использованне в асбестоцемситиом пронзводстве шифера и труб, целесообразиым было проведение оценки канцерогепиых рисков имснпо среди цанпой груи Iı) работающих.

Целью нсследовапия стала оценка канцерогешной опаспости асбеста для работающих на асбестоцемснтиых ироизводствах.

\section{Материалы и методы исстедования}

Аналитнческое обобщешн даных паучной литературы проведено с нспользованием ручного по- иска ниформацин в библиотечных и электроныв базах дапшых. Цля понска ипформациониых источпнков в Иитернете нспользована мсждупародная понсковая систсма «Google» и электропная Нıтерпет-энциклопедия «Внкипедия» (объсм базы апглийского сегмепта па момепт исслсдовання 1,5 мліг. статей).

Оцсика канцерогеной опасностн среди работающих асбестоцемситпой промышлениостн проводилась с использованием мета-анализа по методологни снстематичсских обзоров, разработаниых The Cochrane Collaboration $[8,12,31]$. Llля оцеики канцсрогениого риска среди работников асбестоцемситной промынленности был проведеи целевой отбор напиых о результатах когортиых нсследованнӓ с использованисм баз дапшых Medline за пернод 1986-2004 гг. Характернстика 14 когортІых нсследовапий 10 аналнзу рисков смертиости, включсиных в нсследование, представлена в таблице 1 .

Даншые отобраниых исслецований были обобцсшы методом кумулятивного мета-анализа, в зависнмости от професснональной экспознции работающих асбсстами: хризотил $(100,0 \%)(n=4$ данпых когортиых исследований); хрнзотил +крикодолит $(11=3)$; хрнзотил + крокидолит +амознт $(n=7)$ н апатомнческой локализации злокачествениых повообразований. Во врсмя статнстического обобщсиия были нсключешы неодиородиые паниые. Мста-анализ проводили с использованнем модели фнксированиьх эффектов.

\section{Результаты исследования и их обсуждение}

Промышленно-экономическое значение асбестоцементных изделий и их производство в Украине. Қ асбестоцементиым издслиям отиосятся - кровслылыс матерналы (асбестоцементная плитка, листы облицовочиые и кровельныс) и асбестоцемеитныс нанорные и безпапорные трубы, муфты, короба, подокониые и электронзоляцнопиые доски, изделия специального назиачения, малье архитектурные формы (нветочницы, вазы н пр.) $[1,2,10,11,16-19]$

Пронзводство асбестоцементного шифера в

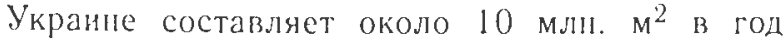
(50-60\% емкости рылка скатных кровсль). В послединс годы наблюдаются высокис темпы развитня рынка кровелыных матерналов в Украние, что обусловлено высоким спросом на иниферлыс кровли нз-за нх иевысокой цены $\left(1-2 \$ / \mathrm{M}^{2}\right)$ и колсервативности прсдночтенй массовых застройнциов, 
Таблица 1

Характеристика когортных исследований по оценке уровня относительного риска смертности работающих на асбестоцементных производствах, включенных в мета-анализ

\begin{tabular}{|c|c|c|c|c|}
\hline $\begin{array}{l}\text { Год } \\
\text { публи- } \\
\text { кация }\end{array}$ & $\begin{array}{l}\text { Asтop } \\
\text { [нсточmuk uнформациа] }\end{array}$ & $\begin{array}{l}\text { Исследуемыне когорты } \\
\text { на пронзводствах }\end{array}$ & $\begin{array}{l}\text { Внды экспознции асбестами } \\
\text { работаноцих } \\
\text { [концентрация в воздухе } \\
\text { рабочені зоны] }\end{array}$ & $\begin{array}{l}\text { Характеристика } \\
\text { когорт и период } \\
\text { наблюдения }\end{array}$ \\
\hline 1986 & Gardner et al. [28] & $\begin{array}{l}\text { Асбестоцементный } \\
\text { завод, Англия }\end{array}$ & $\begin{array}{c}\text { Хризотил }(99,99 \%), \text { амозит } \\
(0,01 \%) \\
{[<1 \text { волокно/мл] }}\end{array}$ & $\begin{array}{l}2167 \text { чел., } 42 \text { года } \\
(1941-1983 \text { гт.) }\end{array}$ \\
\hline 1987 & Hughes et al. [39] & $\begin{array}{c}2 \text { асбестоцементных } \\
\text { завода, США (Новый } \\
\text { Орлеан) }\end{array}$ & $\begin{array}{c}\text { Хризотил }(99,0 \%) \\
\text { крокидолит }(0,5 \%), \text { амозит } \\
(0,5 \%) \\
{[1,4 \text { волокно/мл] }} \\
\end{array}$ & 6931 чел., 40 лет \\
\hline $\begin{array}{l}1988 \\
1990\end{array}$ & Albin et al. $[36,49]$ & $\begin{array}{l}\text { Асбестоцементная } \\
\text { промышленность, } \\
\text { Швеция }\end{array}$ & $\begin{array}{c}\text { Хризотил (95\%), крокндолит, } \\
\text { амозит, } \\
\text { (экспозиция - } 1,2-2,3 \\
\text { волокно-год/Мл.) } \\
\end{array}$ & $\begin{array}{l}1929 \text { чел., } 78 \text { лет } \\
(1907-1985 \text { гт.) }\end{array}$ \\
\hline 1989 & Raffn et al. [30] & $\begin{array}{c}\text { Асбестоцементная } \\
\text { промышленность, } \\
\text { Дания }\end{array}$ & $\begin{array}{c}\text { Хризотил (89\%), амозит } \\
(10 \%), \text { крокидолит }(1 \%), \\
{[0,5-2,0 \text { волокно/мл] }}\end{array}$ & $\begin{array}{l}8580 \text { чел., } 56 \text { лет } \\
(1928-1984 \text { гг.) }\end{array}$ \\
\hline 1990 & Parnes et al. [42] & $\begin{array}{c}\text { Асбестоцементная } \\
\text { промышленность, США }\end{array}$ & $\begin{array}{c}\text { Хризотил }(100,0 \%) \\
\text { [не определено] }\end{array}$ & 2057 чел., 3 года \\
\hline 1991 & Botta et al. [37] & $\begin{array}{c}10 \text { асбестоцементных } \\
\text { заводов, Италия }\end{array}$ & $\begin{array}{l}\text { Хризотил }(99,0 \%) \\
\text { крокндолит }(1,0 \%) \\
\text { [не определено] }\end{array}$ & $\begin{array}{l}3367 \text { чел., } 79 \text { лет } \\
\text { (1907-1986 гг.) }\end{array}$ \\
\hline 1993 & Gurvich E.B., et al. [27] & $\begin{array}{l}\text { Асбестоцементная } \\
\text { промышленность, } \\
\text { Росия } \\
\end{array}$ & $\begin{array}{l}\text { Хризотил }(100,0 \%) \\
\text { [не определено] }\end{array}$ & $\begin{array}{c}37 \text { лет } \\
(1949-1988 \text { гт.) }\end{array}$ \\
\hline 1994 & Giaroli et al. [40] & $\begin{array}{l}\text { Асбестоцементная } \\
\text { промышленность, } \\
\text { Италия } \\
\end{array}$ & $\begin{array}{l}\text { Хризотил, крокидолит } \\
{[1-44,0 \text { волокон/мл] }}\end{array}$ & $\begin{array}{l}3341 \text { чел., } 34 \text { лет } \\
\text { (1955-1989 гг.) }\end{array}$ \\
\hline 1994 & Jakobsson et al. [22] & $\begin{array}{l}\text { Асбестоцементная } \\
\text { промышленность, } \\
\text { Швеция }\end{array}$ & $\begin{array}{c}\text { Хризотил (95\%), хрохидолит } \\
\text { и амозит (5\%) } \\
\text { [не определено] } \\
\end{array}$ & $\begin{array}{c}2507 \text { чел., } 31 \text { год } \\
(1958-1989 \text { гг.) }\end{array}$ \\
\hline $1996 a, 6$ & Raffn et al. $[26,34]$ & $\begin{array}{c}\text { Асбестоцементная } \\
\text { промышленность, } \\
\text { Дания } \\
\end{array}$ & $\begin{array}{c}\text { Хризотил (89\%), амозит } \\
(10 \%), \text { хрокидолит (1\%), } \\
{[0,5-2,0 \text { волокно/мл] }}\end{array}$ & $\begin{array}{c}8463 \text { чел., } 62 \text { года } \\
\text { (1928-1990 гг.) }\end{array}$ \\
\hline 1997 & $\begin{array}{l}\text { Szeszenia-Dabrowska N. } \\
\text { et al. [48] }\end{array}$ & $\begin{array}{l}4 \text { асбестоцементных } \\
\text { завода, Польша }\end{array}$ & $\begin{array}{c}\text { Хризотил (85\%), крокндолит } \\
\text { и амозит (15\%) } \\
{[10,0-20,0 \text { волокно/мл] }}\end{array}$ & $\begin{array}{l}4712 \text { чел., } 46 \text { лет } \\
\text { (1945-1991 г.г.) }\end{array}$ \\
\hline 2002 & Coviello V. et al. [38] & $\begin{array}{c}\text { Асбестоцементный } \\
\text { завод, Италия }\end{array}$ & $\begin{array}{l}\text { Хризотил, крокидолит } \\
\text { [не определено] }\end{array}$ & $\begin{array}{l}417 \text { чел., } 23 \text { года } \\
(1972-1995 \text { гг.) }\end{array}$ \\
\hline 2004 & Smailyte et al. $[46,47]$ & $\begin{array}{c}\text { Асбестоцементная } \\
\text { промышленность, Литва }\end{array}$ & $\begin{array}{l}\text { Хризотил }(100,0 \%) \\
\text { [не определено] }\end{array}$ & $\begin{array}{l}1887 \text { чел., } 44 \text { лет } \\
(1956-2000 \text { гг.) }\end{array}$ \\
\hline
\end{tabular}

особенно в сельской местности. По данным Государственного комитета статистики, производство асбестоцементного шифера в Украине в 2003 году составило 707 млн. условных плит.

Альтернативой асбестоцементному шиферу в Украине являются следующие кровелыные материалы: металлочерепнца (производство $-4,5$ млн. м $^{2}$ ) и элитная металлочерепица ( 45 тыс. м $^{2}$ ); еврошифер $\left(1,6\right.$ мли. м $\left.{ }^{2}\right)$, битумная черепица $\left(0,4\right.$ млн. м $\left.^{2}\right)$, керамическая и цементно-песчаная черепица $(1,4$ млн. м²) $[1,2,11]$. Сравнительные характеристики кровельных материалов приведены в таблице 2.

Асбестоцементные трубы в советское время были фондируемым материалом и использовались 
Tabisulu 2

Характеристика кровельных матерналов, используемых на территории Украины

\begin{tabular}{|c|c|c|c|}
\hline $\begin{array}{l}\text { Вид кровельного } \\
\text { материала }\end{array}$ & $\begin{array}{l}\text { Используемые матерналы } \\
\text { для пронзводства }\end{array}$ & $\begin{array}{l}\text { Стонмость } \\
\left(\$ / 1 \mathrm{M}^{2}\right)\end{array}$ & $\begin{array}{l}\text { Наличие пронзводства } \\
\text { в Украние }\end{array}$ \\
\hline Асбестоцементный шифер & Цемент*, хризотил-асбест* & $1,0-2,0$ & 10 предприятий \\
\hline Еврошифер & Органические волокна*, битум*, полимеры & $3,5-5,3$ & 1 предприятие \\
\hline Пластиковые кровли & $\begin{array}{l}\text { Акрил ("оргстекло"), поливинилхлорид", } \\
\text { поликарбонат }\end{array}$ & $5,0-33,0$ & Отсутствует \\
\hline $\begin{array}{l}\text { Металлополимерный } \\
\text { шифер, металлочерепица } \\
\text { ("профнастил") }\end{array}$ & $\begin{array}{l}\text { Листовая (рулонная) сталь, алюминиево- } \\
\text { цинковое и полимерное* покрытия }\end{array}$ & $8,0-12,0$ & 7 предприятий \\
\hline Керамическая черепица & Глина, пластификаторы* & $14,0-35,0$ & 4 предприятия \\
\hline $\begin{array}{l}\text { Цементно-песчаная } \\
\text { черепица }\end{array}$ & Цемент*, кварцевын песок* & $7,0-18,0$ & 1 предприятие \\
\hline Полимер-песчаная черепица & Полимер* (30\%), кварцевый песок* $(70 \%)$ & $7,6-10,0$ & 5 предприятий \\
\hline Битумная черепица & Стеклохолст, битум*, клей, базальт * & $5,0-40,0$ & 3 предприятия \\
\hline
\end{tabular}

Примечание: " - потенциально канцерогеноопасные факторы при пронзводстве кровельного материала

практически полностью в мелиоративных сооружениях среднеазиатских республик. В настоящее время асбестоцементные трубы используются для подачи горячей воды в открытых и закрытых тепловых сетях холодного и горячего хозяйственно-питьевого водоснабжения (давление до 1,6 МПа, температура до $115^{\circ} \mathrm{C}$ ), являясь альтернативой металлическим трубам; для устройства канализации (безнапорные трубы), газопроводов и сетей механизированного орошения полей. Коэффициент теплопроводности у асбестоцемента в 140 раз ннже, чем у стали, а стенка трубы толще, чем у стальной, в 3-4 раза, поэтому при использовании асбестоцементной трубы допускается применение упрощённой теплоизоляции - засыпной (керамзит, граншлак), а в случае применения пенополиуретановой теплоизоляции - её слой в три раза тоньше, чем на стальной трубе. Кроме того, асбестоцемент является хорошим диэлектриком, поэтому трубопроводы из него не подвержены электрохимической коррозии под действием блуждающих токов и пе нуждаются в гидроизоляции. Поэтому им нет равноценной замены в промышленных зонах, городах с электротранспортом и на железнодорожных станциях, где все магистрали расположепы вдоль путей.

Сегодня рынок предлагает великое множество самых различных труб - чисто стальных, стальных с различными покрытиями, нержавеющих, труб из цветных металлов, полимерных, металлопластиковых, керамических, высокопрочных чугунных с шаровидным графитом. Но все опи не обладают теми свойствами, которые имеются у асбестоцементных труб - низкой стоимостью, долговечностью, простотой при моІтаже в любых условиях. Так, стальная водогазопроводная труба до 100 мм стоит более $10,0 \$ / \mathrm{m}$, а асбестоцементная $-2,0 \$ / \mathrm{m}$. Все это и определяет промышленно-экономическое преимущество асбестоцементных труб $[1,2,11]$.

Қ числу лидеров асбестоцементного пронзводства в Украине относятся: ОАО «Ивано-Франковский цементно-шиферный комбинат» (проектная мощность -325 млн. условных плит в год, рыночная доля - более $40 \%$ ), ОАО «Қраматорский цементно-шиферный комбинат» («Пушка») (295 мли. плит/год) и ОАО «Донцемент» (г. Амвросиевка Донецкой обл.) (83 мли. плит/год). Асбоцементный лист производят также ОАО «Балцем» (г. Балаклея Харьковской обл.), киевское ОАО «Асбодревстекло» [11].

Асбестоцемент - это фибробетон (бетон, армированный волокном). Полученный с добывающего предприятия асбест мехапически измельчают и раслушают до разделения волокон, добавляют воду и портландцемент: для листовых изделий (шифер) асбеста $10-18 \%$ и цемента $82-90 \%$ по массе; для труб - соответственно 15-21 и 79-82\%. Асбест в таком материале находится в связапном состоянии и практически не выделяется в окружающую среду. Дляя производства асбестоцементных изделий в УКранне используется отечественный портландцемент $\left[\mathrm{CaO}-60-70 \%, \mathrm{SiO}_{2}-19-24 \%, \mathrm{Al}_{2} \mathrm{O}_{3}-\right.$ $4-7 \%, \mathrm{Fe}_{2} \mathrm{O}_{3}-2-6 \%, \mathrm{MgO}$ до $5 \%$ ], российский хризотил-асбест (синонимы: серпентин, белый асбест) $\left[\mathrm{Mg}_{3}\left(\mathrm{Si}_{2} \mathrm{O}_{5}\right)(\mathrm{OH})_{4}\right]$ (добыча - OAO «Ураласбест» Свердловская обл., г. Асбест) $[1,2,7,11$, 16-19]. 
Технология изготовления асбестоцементиых 113делий содержит ряд процессов:

1) обминание и распушивание асбеста в присутствии воды вначале на бсгупах, а затем в голлендерах до получения возможно более топких волокон; в этих же голлсндерах - тщательюос смешинапие распушенюго асбеста с цемсптом и разжиженис получспюй асбестоцемснтпой смеси водой;

2) формованне изделий в формовочиых машипах;

3) предварительюе твердение, тепловая обработка сформованиых изделий и мехапическая обработка (обрезка, волиировка) асбестоцементиых издслнй $[1,2,14]$.

Патогенетические механизмы канцерогенеза производственных химических факторов асбестоцементного производства. Осповцыми факторами канцерогенюго риска среди работпиков асбестоцсментиого пронзводства являяются асбест и двуокись кремния, отнесеншы IACR к первой группе канцерогенюй опаспости человска [16-19].

Aсбест является как иццуцирующим, так и промотируюшим канцерогеншым агсптом. Обладая собствспными канцерогешными свойствами, оІ усиливаст капщерогенпость других факторов канцерогспеза (двуокиси кремпия, курения и др.). При этом, асбесты, относясь к эпигенетнческим канцерогенам (пе вызывающим прямого мутациониого повреждения ДНІК клеток-мишеней), обладают упикалыной способностью повреждать геном клетки мишени. Между ншцукцией непластической трансформации в органахминенях и дозой ишгаляциопного поступившего асбеста существует четкая линсйная закономерпость. Мехапизмы канцерогепного действия волокон асбеста ассоциируются с образовапием в органах-мишегях активцых форм кислорода цвумя путями:

- первый - под влиянием $\mathrm{Fe}^{2+}$, содержащегося в больном количестве в волокиах амфиболовых асбестов (амозит, антифилит, актинолит, крокидолит - содсржание $\mathrm{FeO} / \mathrm{Fe}_{2} \mathrm{O}_{3}-34,0-$ $44,0 \%$ ) и в пебольшом количсстве в асбестахсерпентилах (хризотнл-асбесте $-0,3-4,0 \%$ ), кислород восстанавливается до супероксида с последуюцей дисмутацией до перекиси водорода с образованием гндроксирадикала;

- второй - фагоциты активизнруются (повреждаются) асбестовыми волюкиами длиной болес 10 мкм («длиниые волокна»), что ведет к иродуктированию в иих активных форм кислорода («оксидантиый стресс»), которыс в далыгйпІем попадают в клетки-мишени.
Образовавниеся активныс формы кислорода вызывают прямос повреждение ЦНК клеток оргаиов-миненей путсм окнсления гуапниа с образоваиисм 8-гидроксигуапина, который становится инициатором непластнческой трансформацин клетокмишеисй $[13,16-19]$.

Кроме того, асбесты обладают способностью прямого повреждения клеток органов-мингенсй пропикая в клетку-мишеш, волокша цлиной до 10 мкм («короткне волокиа») вызывают позреждение веретела деления шри митозе, фрагмеитацио хромосом, с образованием микроядер, прнлигание волоког к хромосомам [1.3].

В свою очередь, волокиа хрнзотил-асбеста не обладают кислотоустойчиностью (в отличие от амфиболовых волокон) н, попав в дыхательлую систему, под дейстзием кислой среды организма частичноо растворяютея, а частнчно вызодятся (период полувынедения - от 7 часов до 10 суток) [9]. Кромс того, в хризотил-асбесте содержапие $\mathrm{Fe}^{2+}$, являюцегося осповным фактором ицициации канцерогенеза, в 10 раз меньце, чсм у амфибол-асбестов [23].

I роведениыми экспериментально-гигиенитескими исследовапиями было установлено, "то иигаляццопшая доза асбеста, которая вызываст дополпительпе увеличение относительног рнска развития рака легкого составляет: для чистых и смешанишых амфиболовых асбестов (амозит, крокнцолит) - 21 волокно/мл, - Год; для хризотилового асбеста - I667 волокіо/мл.-год, то ссть в 79 раз меньше. Қанцерогениая онасность асбестов прямо пропорциональна нх суммарной цозе, поступающсй и пакапливающцейся в оргапах-минепях $[23$, $29,13,41]$.

Исследованиями показано, что в процессе эксплуатации асбестонемента с его поверхности эмитируют не чнстые хризотнл-асбестовые волокна, которые первопачально вводят в асбестоцемептную композицию, а продукты гидратацин клинкериых фаз портландцемеита и последуюпей их карбопизации. Межыцу продуктамн гндратации и поверхностыо асбестовых волокон установлено химнчсское взаимодействис, а также увеличение количсства железа ( от 3,0 цо 6,0\%) при иензменпом количестве кремлия $(42,0 \%)$. Установлено также изменспие поверхиостиых свойств волокои хризотнл-асбеста и нх структуры как цод действием цементиой матрицы, так и воздуха окружаюнцей среды: изменешие структуры волокош в внде иерехода из клинохризотила в ортохрнзотил н даже к 
полностью аморфнзиронанцому состоянию н изме пения параметров элементарной ячейки крнсталлической решетки [4-6]. При таких измспсииях структуры волокоп хрнзотил-асбеста под действнем портлапдцемептной матрнцы н воздуха окружа юнсй среды его биологичсская актнвность сннжается в 10-30 раз, что обусловливает его безопасность для паселения при цлительой эксплуатацин $[3,7,9]$.

Кромс воздействня асбеста, работннки асбестоцементных грсдприятий подвержены вредиому влиянию кристаллических форм двуокиси кремния (криспьобалита, кварца), содержащихся в цемеите (около 50\%). Крнсталлический кремпий в легочиой ткани вызывает повреждение эпителия н активнзацию макрофагов и нейтрофильных лим фоцитов, вследствие чего в повреждешых тканях угеличивается концентрация факторов воспалеиня и клеточной пролиферации (цитокннов), въ) зывающих пролиферацию эпителия и илтерстициалыпых клеток (клинически проявляюшцюся пневмосклерозом). Одновременно пронсходит активнзация фагоцитов крнсталлами двуокисн крсмния, что так жс, как и прн действин асбестовых волокон, ведет $к$ развнтию «оксндантиого стресса» кашисрогснеза $[44,45]$.

Такнм образом, асбест и двуокись кремния нмсот общие механизмы в нинцализации канцерогенеза в клетках оргапов-мишеней за счст повреждспия в пих ДНК, обусловленного «окидантым стрессом» вследстине первичного поврежлсния макрофагов “длнишыми» волокнамн асбеста и кристаллами двуокиси кремиия. Қроме того, процесс кашцерогешсза усиливается пря мым поврсждаюшим эффсктом ДНК от воздействня «коротких» асбестовых волокон и воспалительпой стимуляцисй пролифсрацин клеток орга пов-мишеней факторами воспалелия, вызываемыми кристаллами двуокиси кремния. Вес это и обусловливает патогспетнческие особепности в формировании профессионального канцерогенного риска среди работников асбестоцементиого пронзводства.

Риск возникновения злокачественных новообразований среди работников, подвергающихся производственной экспозиции асбестами (по данным научной литературы). Миожествениыми эпндсмиологнческимн нсследованиями доказано повынение риска возннкиовеиня рака легких и мсзотелномы плевры у работаю- щих, экспопированшых иа пронзводстве асбсстами. Так, устаповлено, что количество случасв злокачествениых иовообразований прн этом увеличнвастся пропорционально продолжнтсльности професснональной экспознцин асбестом или его сложІыми смесямн, а относитсльыый рнск (RR) в когортиых исследования оценивается на уровне $2,0-5,0$ (рак легкого) н 3,0-15,0 (мезотелнома плевры ) $[16-21,25,32,41,50,51]$. Установлено, что курение, на фоне професснональной зкспознции асбестами, зиачительно повышает рнск развнтия рака легких н не влияст на рнск возникиовення мезотелиомы глсиры [16-19, 33, 50].

При оценке каншерогеноло рнска ирн професснональной экспознцин работающих хризотил-асбестом в большей частн нсследований не отмечено увеличешие риска рака легкого нли отмечается его незначитсльнс увсличсние ( $\mathrm{RR}=1,0-2,0) . \wedge \mathrm{pнск}$ развнтия мезотелиомы плевры после экспознции хризотиловым асбестом составляет 1/50 от риска, вызванного амфиболовыми асбестами (крокндолитом). Также хризотиловый асбест, в отличнс от амфиболовых, пе вызываст мезотелномы бношины $[16-19,21,25,32,35,41,50]$.

Нсследованиями также установлепь связи между профессноналиой экспозицней асбестамн и возникновенисм злокачественых повообразоваинй гортани - 1,9-2,4, а срсди работников шахт по добыче хрнзотнлового асбеста этот риск сще больший $(3,2)[16-19,24,25,32,41]$.

Существуют энндемнологнческие даниые об увеличенни рнска возникиовения рака органов гынпеварения среди работинков, экспонированиых асбестом. Так, рнск рака желудка, толстой и ирямой кишки увеличивастся до 2,0-4,0. Также имеются доказательиые даниые, указываюцие па увеличение рисков развития рака желчиьх протоков печени, крупноклеточной лимфомы органов пинце варения и полостн рта $[16-19,21,24,41]$.

Paпее провсдспиым мста-аналнзом (метод невзвешениых отношений и случайная модель эффектов) было установлено, что риск возникиовсния злокачествениых повообразованнй, а также смерти от них среди когорт рабочих, которыс подвергаются экспознцни хрнзотнл-асбеста, были увсличещы для всех смсртелыных случасв ( $\mathrm{RR}=1,28)$ и апатомнгеских локалнзаций ( $R \mathrm{R}=1,26)$ : органов дыхания $(\mathrm{RR}=2,24)$, в т.ч. легких $(\mathrm{RR}=2,29)$; органов пищеварения $(\mathrm{RR}=1,27)$. Рнски развития рака легкнх значитслыло повынены срсдн работннков: текстильпых фабрнк по пронзводству асбесто-во- 
локонных тканей $(\mathrm{RR}=3,64)$; на заводах по пронзводству асбестовых изделий $(\mathrm{RR}=3,07)$; в карьерах по добыче и заводах по обогащению асбеста шахтеры и размольщики $(\mathrm{RR}=2,24)$; на асбестоцементных заводах $(R R=1,22)$. Риски развития рака органов пищеварения были увеличены средн работников заводов по изготовлению асбестовых изделий $(\mathrm{RR}=1,48)$. Увеличенне рнска мезотелиомы плевры не было выявлено [15].

В тоже время, данные многочнсленных эпидемнологических исследований указывают на увеличение риска развития рака легких при профессио- нальной экспозиции кварцем и кристобалитом $(\mathrm{RR}=1,5-6,0)[43-45]$.

Относительный риск смертности работаючих в асбесточементной промыцленности от злокачественных новообразований различной локализации (по данным кумулятивного мета-анализа когортных ретроспективных исследований). Обобщенные данные когортных исследований риска смертностн от злокачественных новообразований среди работников асбестоцементной промышленности представлены в таблице 3.

Таб̆пแ 3

Данные когортных исследований по оценке относительного риска смертности от злокачественных новообразований среди работников асбестоцементной промышленности

\begin{tabular}{|c|c|c|c|c|c|c|c|}
\hline \multirow{2}{*}{$\begin{array}{l}\text { Aвтор } \\
\text { [источнкк информапни] }\end{array}$} & \multicolumn{7}{|c|}{$\begin{array}{l}\text { Oтноситепвий риск смертпости от злокачественныхх новообразований в когорте } \\
\text { шрофессиональн экспонированных асбестами }\end{array}$} \\
\hline & Ротоглотка & Гортань & Лerkoe & Плевра & Пищевод & Желудок & $\begin{array}{c}\text { Tолстая и } \\
\text { прямая } \\
\text { кникеа }\end{array}$ \\
\hline Gardner et al., 1986 [28] & - & $\begin{array}{c}0,91 \\
(0,02-5,06)\end{array}$ & $\begin{array}{c}(\mathrm{M}) 0,90 \\
(0,60-1,30) \\
(\nVdash) 1,40 \\
(0,50-3,10)\end{array}$ & - & $\begin{array}{c}0,29 \\
(0,01-1,59)\end{array}$ & $\begin{array}{c}1,09 \\
(0,61-1,81)\end{array}$ & $\begin{array}{c}0,71 \\
(0,36-1,28)\end{array}$ \\
\hline Hughes et al., 1987 [39] & $\begin{array}{c}0,90 \\
(0,45-1,61)\end{array}$ & $\begin{array}{c}0,56 \\
(0,11-1,62)\end{array}$ & 1,34 & - & $\begin{array}{c}0,93 \\
(0,48-1,62)\end{array}$ & $\begin{array}{c}1,13 \\
(0,71-1,71)\end{array}$ & $\begin{array}{c}0,90 \\
(0,56-1,38)\end{array}$ \\
\hline $\begin{array}{l}\text { Albin et al., } 1988,1990 \\
{[36,49}\end{array}$ & - & - & $\begin{array}{c}1,80 \\
(0,90-3,7)\end{array}$ & $\begin{array}{c}7,2 \\
(0,97-54,0)^{*}\end{array}$ & $\begin{array}{c}1,0 \\
(0,5-2,0)\end{array}$ & $\begin{array}{c}1,7 \\
(0,2-3,3)\end{array}$ & 3,4 \\
\hline $\begin{array}{l}\text { Raffn et al., 1989, } 1996 \\
\text { [30] }\end{array}$ & $\begin{array}{c}0,79 \\
(0,42-1,35)\end{array}$ & $\begin{array}{c}1,66 \\
(0,91-2,78)\end{array}$ & $\begin{array}{c}1,80 \\
(1,54-2,10)\end{array}$ & $\begin{array}{c}5,46 \\
(2,62-10,1)\end{array}$ & - & $\begin{array}{c}1,43 \\
(1,03-1,93)\end{array}$ & $\begin{array}{c}1,47 \\
(1,05-2,01)\end{array}$ \\
\hline Parnes et al., 1990 [42] & $\begin{array}{c}1,83 \\
(0,37-5,19)\end{array}$ & - & - & - & - & - & - \\
\hline Botta et al., 1991 [37] & - & $\begin{array}{c}0,70 \\
(0,23-1,64)\end{array}$ & $\begin{array}{c}\text { (M.) } 2,71 \\
(2,23-3,27) \\
(* .) 3,96 \\
(1,59-8,16)\end{array}$ & - & - & $\begin{array}{c}(\mathrm{M} .) 0,81 \\
(0,47-1,30)\end{array}$ & $\begin{array}{c}\text { (M.) } 0,65 \\
(0,33-1,17)\end{array}$ \\
\hline $\begin{array}{l}\text { Gurvich E.B. et al., } 1993 \\
\text { [27] }\end{array}$ & - & - & $<1,00$ & $<1,00$ & - & - & - \\
\hline Giaroli et al., 1994 [40] & $\begin{array}{c}0,00 \\
(0,00-1,37)\end{array}$ & $\begin{array}{c}0,82 \\
(0,15-2,59)\end{array}$ & $\begin{array}{c}1,24 \\
(0,91-1,66)\end{array}$ & 4,11 & - & - & - \\
\hline Jakobsson et al., 1994 [22] & - & - & - & - & - & - & $\begin{array}{c}\text { (M.) } 1,47 \\
(0,96-2,15)\end{array}$ \\
\hline $\begin{array}{l}\text { Raffn et al., } 1996 \\
{[26,34]}\end{array}$ & - & - & - & - & - & - & - \\
\hline $\begin{array}{l}\text { Szeszenia-Dabrowska N. } \\
\text { et al., } 1997[48]\end{array}$ & - & - & - & 2,12 & - & - & 2,14 \\
\hline $\begin{array}{l}\text { Coviello V. et al., } 2002 \\
{[38]}\end{array}$ & - & - & $\begin{array}{c}1,90 \\
(1,9-2,77)\end{array}$ & $\begin{array}{c}15,0 \\
(4,31-40,81)\end{array}$ & - & - & - \\
\hline $\begin{array}{l}\text { Smailyte et al., } 2004 \\
{[46,47]}\end{array}$ & - & $\begin{array}{c}1,40 \\
(0,70-2,90)\end{array}$ & $\begin{array}{c}\text { (M.) } 0,90 \\
(0,70-1,30) \\
(\% .) 0,70 \\
(0,10-4,60)\end{array}$ & $\begin{array}{c}\text { (\%.) } 20,10 \\
(2,90-142,0)\end{array}$ & - & $\begin{array}{l}\text { (M.) } 0,9 \\
(0,5-1,5)\end{array}$ & $\begin{array}{l}\text { (м.) } 1,6 \\
(1,0-2,6)\end{array}$ \\
\hline Li L. et al., 2004 [15] & - & - & 3,30 & - & - & 1,49 & - \\
\hline
\end{tabular}


Тaблแй 4

Данные кумулятивного мета-анализа относительных рисков смертности от злокачественных новообразований среди работников асбестоцементных промышленности в зависимости от экспозиции их различными видами асбеста

\begin{tabular}{|c|c|c|c|c|}
\hline \multirow[b]{2}{*}{$\begin{array}{l}\text { Локализация } \\
\text { локачественнихх } \\
\text { новообразовантй }\end{array}$} & \multicolumn{4}{|c|}{ RR (C195\%) } \\
\hline & $\begin{array}{c}\text { Хрнзотил-асбест } \\
.(\mathrm{n}=11)\end{array}$ & 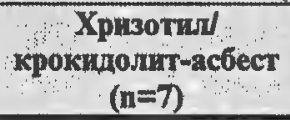 & $\begin{array}{c}\text { Хрнзотил/кроксидолит! } \\
\text { амозит-асбест } \\
(\mathrm{n}=19)\end{array}$ & $\begin{array}{c}\text { Без учета вица } \\
\text { асбеста }\end{array}$ \\
\hline Ротоглотка & $\begin{array}{c}1,83^{*} \\
(0,37 \div 5,19)\end{array}$ & $0,37^{*}$ & $\begin{array}{c}0,85 \pm 0,06 \\
(0,44 \div 1,48)\end{array}$ & $\begin{array}{l}0,88 \pm 0,65^{*} \\
(0,31 \div 2,38)\end{array}$ \\
\hline Гортань & $\begin{array}{c}1,16 \pm 0,25 \\
(0,36 \div 3,98)\end{array}$ & $\begin{array}{c}0,76 \pm 0,06 \\
(0,19 \div 2,12)\end{array}$ & $\begin{array}{l}1,11 \pm 0,55^{*} \\
(0,51 \div 2,20)\end{array}$ & $\begin{array}{c}1,01 \pm 0,39 \\
(0,35 \div 2,77)\end{array}$ \\
\hline Лerkoe & $\begin{array}{c}0,98 \pm 0,18 \\
(0,48 \div 2,58)\end{array}$ & $\begin{array}{l}1,82 \pm 0,96^{*} \\
(1,57 \div 3,38)\end{array}$ & $\begin{array}{c}2,06 \pm 0,74 \\
(1,22 \div 2,90)\end{array}$ & $\begin{array}{c}1,75 \pm 0,87 \\
(1,19 \div 3,01)\end{array}$ \\
\hline Плевра & $\begin{array}{c}2,90^{*} \\
(2,90 \div 148,0)\end{array}$ & $\begin{array}{c}6,64 \pm 6,07^{*} \\
(4,31 \div 40,81)\end{array}$ & $\begin{array}{c}4,93 \pm 2,11 \\
(1,80 \div 32,05)\end{array}$ & $\begin{array}{c}5,37 \pm 4,40 \\
(2,70 \div 61,73)\end{array}$ \\
\hline Пищевод & $\begin{array}{c}0,29^{*} \\
(0,01 \div 1,59)\end{array}$ & - & $\begin{array}{c}0,97 \pm 0,03 \\
(0,49+1,81)\end{array}$ & $\begin{array}{c}0,74 \pm 0,32 \\
(0,33 \div 1,74)\end{array}$ \\
\hline Желудок & $\begin{array}{c}1,00 \pm 0,09 \\
(0,55 \div 1,66)\end{array}$ & - & $\begin{array}{c}1,31 \pm 0,31 \\
(0,61 \div 2,06)\end{array}$ & $\begin{array}{c}1,22 \pm 0,30 \\
(0,59 \div 1,93)\end{array}$ \\
\hline Толстая и прямая кишка & $\begin{array}{c}1,16 \pm 0,45 \\
(0,68 \div 1,94) \\
\end{array}$ & $\begin{array}{c}0,65^{*} \\
(0,33 \div 1,17)\end{array}$ & $\begin{array}{l}1,83 \pm 0,89^{*} \\
(0,93+3,63)\end{array}$ & $\begin{array}{l}1,51 \pm 0,85^{*} \\
(0,77 \div 2,79)\end{array}$ \\
\hline \multirow{2}{*}{$\begin{array}{c}\text { RR } \\
\text { от вида acбеста }\end{array}$} & \multirow[t]{2}{*}{$\begin{array}{c}1,23 \pm 0,67 \\
(0,67+15,37)\end{array}$} & $\begin{array}{l}2,67 \pm 4,08^{*} \\
(1,22 \div 7,22)\end{array}$ & $\begin{array}{l}1,94 \pm 1,55^{*} \\
(0,84 \div 5,76) \\
\end{array}$ & $\begin{array}{l}1,94 \pm 2,38^{*} \\
(0,87 \div 8,93)\end{array}$ \\
\hline & & & $\begin{array}{l} \pm 2,67 \\
\div 15,37)\end{array}$ & \multirow[t]{3}{*}{ 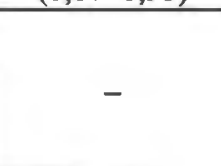 } \\
\hline \multirow{2}{*}{$\mathbf{P}$} & \multirow{2}{*}{\multicolumn{2}{|c|}{$>0,05$}} & - & \\
\hline & & & 0,05 & \\
\hline
\end{tabular}

Примечание: * $-P>0,05$.

Проведенным нами кумулятивным мета-анализом данных когортных исследований по оценке относительного риска смертностн от злокачественных новообразований среди работников асбестоцементной промышленности установлено, что средний относительный риск (RR) смерти от злокачественных новообразованнй без учета внда асбеста у иих увеличен для: мезотелиомы плевры $(\mathrm{RR}=5,37$, $P>0,05)$, рака легких ( $R R=1,75, P<0,05)$, желудка $(\mathrm{RR}=1,22, \mathrm{P}<0,05)$, толстой и прямой кишки $(R R=1,51, P>0,05)$ (табл. 4).

В зависимости от вида асбеста, который использовался в асбестоцементном пронзводстве, относительный риск смертности от злокачествен ных новообразований распределяется следующим образом: смесь хризотил/крокидолит/ амозит-асбестов $(\mathrm{RR}=1,94 ; \mathrm{Cl} 95 \%=0,84-5,76)$; смесь хрнзотил/крокидолит-асбестов $(2,67$; $1,22-7,22)$; чнстый хризотил-асбест $(1,23$; $0,67-15,37)$. Таким образом, достоверные различия в данных относительного риска возникновения всей онкологической патологии среди работников асбестоцементных пронзводств отсут- ствуют, что может быть обусловлено наличием различных концентраций асбеста в атмосфере рабочей зоны, не учитываемой при проведении данного исследования.

Проведенным мета-анализом также установлено, что смертность от злокачественных новообразований пищевода не является специфичной для профессиональной экспозиции работающих асбестом. В то же время, при экспозиции смесью хризотил/крокндолит/амозит-асбесты наблюдается значительное увеличение относительного риска смертности от злокачественных новообразований плевры $(\mathrm{RR}=4,93, \mathrm{P}<0,05)$, легких $(2,06$, $\mathrm{P}<0,05)$, толстой и прямой кишки $(1,83, \mathrm{P}>0,05)$. При воздействин хризотил-асбеста у работающих относительные риски смертности от злокачественных новообразований значительно ниже, чем при воздействии смесей асбеста. При этом повышен относительный риск смерти от мезотелиомы плевры $(R R=2,90, P>0,05)$ и рака ротоглоткн $(R R=1,83, P>0,05)$, однако эти данные не являются достоверными, что требует дополнительных исследований. 


\section{Выводы}

Таким образом, на основапин дашых литературы можно заключить, что хрнзотнл-асбест относится к I группе вешеств, капцерогенпо опасных пля человека. Доказаниыми оргапами-мипенямн цля канисрогеного действия хрнзотил-асбеста являются: прн ишаляционном поступлении - ротоглотка, гортапь, плевра; при элтеральном толстая и прямая кншка. Относитсльный риск возпикповения онкологической патологии, по дапньм мета-апализа когортиых энидемиологнческих нсслецований, ла $52 \%$ лиже, чсм при действии смессй хризотил-асбеста с другими амфиболовыми асбестамн (крокндолитом и амозитом). Учитывая, что дапныс цругих исследовапий указывают на меньший (в 50-80 раз) опкологический риск хризотил-асбеста, чем амфиболовых асбестов, это может указынать па кашиерогениые влияния других производственых факторов в асбестоцсментном пронзводствс. К таковым может быть отнесена пыль двуокиси кремния, который совмсстно с

\section{Литература}

1. Асбестоцементные изделия.- На сайте: http:// www.build-info.net/asbestocement.html

2. Асбестоцементные трубы.- На сайте: http:// www.realestate.net.ua/news 1516.html

3. Биологическое значение поверхностных свойств фиброгенных пылей/А.В. Яхъяев, Б.Т.Величковский, И.Б.Деева, Л.Г.Коркина//Пигиена и санитария.- 1986.- №6.- С. 37-42.

4. Видоизменение поверхности асбестовых волокон в асбестоцементе под действием продуктов твердения цемента/С.М.Нейман, И.Г.Лугинина, А.И.Везенцев, В.В.Турский//Строит. матер.- 2002.- №4.C. $30-31$.

5. Изменение свойств хризотил-асбеста в асбестоцементных изделиях под действием цементного камня и погодных факторов/И.Г.Лугинина, А.И.Везенцев, С.М.Нейман, В.В.Турский//Строит. матер.2001.- №9.- С. 16-18.

6. Исследования хризотил-асбеста, әмитированного с поверхности асбестоцемента, методами аналитической электронной микроскопии/А.М.Горшков, А.И.Везенцев, А.В.Сивцов, С.М.Нейман// Докл. РАН.- 2002.- Т.384, №1.- С. 89-91.

7. К вопросу о безопасном применении асбестоцемента/А.Везенцев, С.Нейман, Е.Гудкова, Л.Наумова//Строит. матер.- 2004.- №4.- С. 38-39.

8. Мальцев В.. Ефимцева Т., Сухин Д. Кому и что нужно доказывать?//Аптека.- 2002.- №24.- На сайте: http://users.iptelecom.net.ua/ s_oracul/dokaz, med.htrn асбестом относится к I групие канцерогенов и можст зызвать синсргические канцерогеные эффекты. Қроме того, иместся необходимость дальшейшего нследовашн роли тяжслых металлов и оксидог железа, которыс могут находиться в хризотнл-асбесте, а такљке красителей, которые использзуютея для окраскн ницфера, в формировании капцерогенной опаспости асбестоцементного гронзводства.

Значительные дисперсиопыс отклопения, получениые при анализе результатов ретроспективпых когортиых нсследований смертности работинков асбестоцемеитиый предпрнятнй, требуют проведепия прослектины когортиых и контролирусмых эпидемиологических исследований па модельпых предгриятиях, с учстом химигеского состава, уровнсй загрязиения воздуха рабочей золы асбестами и бнологически-активными формами двуокиси кремния, с учстом возможиостей постунлепня в оргапизм работающих и других капцерогепюоопасных факторов.

9. Пылев Л.Н., Васильева Л.А., Кулагина Т.Ф. Экспериментальное изучение канцерогенного действия асбеста//Эксперим. онкол.- 1982.- Т.4, №4.C. 3-7.

10. Пылев Л.Н., Смирнов О.В. Онкологическая опасность при производстве и использовании асбестоцементных изделий в быту//Пигиена и санитария.- 2006.- №2.- С. 32-36.

11. Рудавский А. Обзор украинского рынка материалов для скатных кровель//Будмайстер.- 2004.Август.- На сайте: http://portal.stroiserver.com.ua/ modules/news/article.php?storyid=146

12. Фейгин В.Л. Основы мета-анализа: теория и практика//Страница Российского отделения Кокрановского Сотрудничества. - На сайте: http://www.cochrane.ru/mjmp/r7-99-1.htm

13. Химический канцерогенез/В.С.Турусов. Г.А.Белицкий. Л.Н.Пылев, В.А.Кобляков//Канцерогенез/По ред. Д.Г.Заридзе.- С. 204-225.

14. Чаус К.В., Чистов Ю.Д., Лабзина Ю.В. Технология производства строительных материалов, изделий и конструкций.- М.: Стройиздат, 1988.$448 \mathrm{c}$.

15. A meta-analysis of cohort studies on cancer mortality among workers exposure to chrysotile fiber alone/L.Li, T.D.Sun, X.Zhang et al.//Zhonghua. Yu. Fang. Yi. Xue. Za. Zhi.-2004.- V.38, №1.- P. 39-42

16. Asbestos/IARC Monographs.-- IARC, 1973.-- V.2.

17. Asbestos/IARC Monographs.- IARC, 1987.Suppl.7. 
18. Asbestos/IARC Monographs.- IARC, 1987.Suppl.6.

19. Asbestos/IARC Monographs.- IARC, 1977.V. 14.

20. Asbestos and lung cancer: is it attributable to asbestosis or to asbestos fiber burden/D.W.Henderson. N.H.deKlerk, S.P.Hammar et al.//Pathology of lung tumors.- New York: Churchill-Livingstone, 1997.

21. Asbestos selected cancers.- The National Academies Press, 2006.- http://www.nap.edu/catalog/ $11665 . \mathrm{html}$.

22. Asbestos. cement, and cancer in the right part of the colon/K.Jakobsson. M.Albin. L.Hagmar//Occup. Environ. Med.- 1994.- V.51, №2.- P. 95-101.

23. Bernard $W$. The Serpentinite Multisystem Revisited: Chrysotile is Metastable//Int. Geology Rev.2004.- V.46.- P. 479-506.

24. Browne K., Gee J.B. Asbestos exposure and laryngeal cancer//Ann. Occup. Hyg.- 2000.- №44.P. 239-250.

25. Churg A., Green F.H.Y. Occupational lung disease. Pathology of the lung (2nd ed.).- New York, 1995.

26. Colorectal cancer in asbestos cement workers in Denmark/E.Raffn, E.Villadsen, E.Lynge//Am. J. Ind. Med.- 1996.- V.30, №3.- P. 267-272.

27. Epidemiology of chronic. precancerous and oncologic diseases in workers of asbestos and cement industry/E.B.Gurvich, E.V.Gladkova, O.V.Gutnikova. A.V.Kostiukovskaia//Med. Tr. Prom. Ekol.- 1993.№5-6.--P. 4-6.

28. Follow up study of workers manufacturing chrysotile asbestos cement products/M.J.Gardner, P.D.Winter, B.Pannett. C.A.Powell//Br. J. Ind. Med.1986,- V.43, №11.- P. 726-732.

29. Hodgson J.T., Darnton A. The quantitative risks of mesothelioma and lung cancer in relation to asbestos exposure//Ann. Occup. Hyg.- 2000.- №44.- P. 565-601.

30. Incidence of cancer and mortality among employees in the asbestos cement industry in Denmark/ E.Raffn, E.Lynge, K.Juel, B.Korsgaard//Br. J. Ind. Med.- 1989.- V.46, №2.- P. 90-96.

31. Lau J., Ioannidis J.P.A., Schmid Ch.H. Quantitative synthesis in systematic reviews//Ann. Intern. Med.- 1997,- №127,- P. 820-826.

32. Liddell D. Asbestos and cancer (letter)//Ann. Occup. Hyg.- 2001 . - №45.- P. 327-338.

33. Liddell F.D.K. The interaction of asbestos and smoking in lung cancer//Ann. Occup. Hyg.- 2001.№45.- P. 341-356.

34. Lung cancer in asbestos cement workers in Denmark/E.Raffn, E.Villadsen, G.Engholm, E.Lynge// Occup. Environ. Med.- 1996.- V.53, No6.- P. 399-402.

35. Meldrum M. Review of fibre toxicology.-Sudbury: HSE Books, 1996.
36. Mortality and cancer morbidity in cohorts of asbestos cement workers and referents/M.Albin. K.Jakobsson, R.Attewell et al.//Br. J. Ind. Med.- 1990.V.47, №9.-P. 602-610.

37. Mortality from respiratory and digestive cancers among asbestos cement workers in ltaly/M.Botta, C.Magnani, B.Terracini et al.//Cancer Detection and Prevention.- 1991.- V.15, №6.- P. 445-447.

38. Mortality in a cohort of asbestos cement workers in Bari/V.Coviello, M.Carbonara, L.Bisceglia, C.Di Pierri//Epidemiol. Prev.-2002.- V.6, №2.- P. 65-70.

39. Mortality of workers employed in two asbestos cement manufacturing plants/J.M.Hughes, H.Weill, Y.Y.Hammad//Br. J. Ind. Med.- 1987.- V.44, №3.P. $161-174$.

40. Mortality study of asbestos cement workers/ C.Giaroli, S.Belli, C.Bruno, S.Candela//lnt. Arch. Occup. Envir. Health.- 1994.- V.66, №1.- P. 7-11.

41. Occupational Cancer: A guide to prevention, assessment and investigation/AFOM Working Party on Occupational Cancer.- The Australasian Faculty of Occupational Medicine, 2003.- P. 35-39.

42. Parnes S.M. Asbestos and cancer of the larynx: Is there a relationship?//Laryngoscope.- 1990.- V. 100. №3.- P. 254-261.

43. Prodan L., Bachofen G. Цемент и бетон//Энцинлопедия по охране и безопасности труда: 4-е изд.- МОT, 2000.- на сайте: http://base. safework.ru

44. Silica/IARC Monographs.- IARC. 1987.Suppl.7.- P. 341.

45. Silica/LARC Monographs.- IARC, 1997.- V.68.P. 41 .

46. Smailyte G.. Kurtinaitis J., Andersen A. Cancer mortality and morbidity among Lithuanian asbestoscement producing workers//Scand. J. Work Environ. Health.-2004.- V.30. N.1.- P. 64-70.

47. Smailyte G.. Kurtinaitis J., Andersen A. Mortality and cancer incidence among Lithuanian cement producing workers//Occup. Environ. Med.- 2004.- V.61. №6.- P. 529-34.

48. Szeszenia-Dabrowska N., Wilczynska U., Szymczak W. Cancer risk in asbestos-cement industry workers in Poland//Med. Pr.- 1997.- V.48, №5.- P. 473-483.

49. Total and cause-specific mortality in cohorts of asbestos-cement workers and referents between 1907 and 1985/M.Albin. R.Attewell, K.Jakobsson et al.// Arh. Hig. Rada. Toksikol.- 1988.- V.39, №4.- P. 461-467.

50. Trends in occupational groups and industries associated with Australian mesothelioma cases 1979-1995/A.J.Rogers, P.Yeung, A.Johnson et al.// Ann. Occup. Hyg.- 1997.- №4 1 (Supp l.).- P. 123-128.

51. Weiss W. Asbestosis: a marker for the increased risk of lung cancer among workers exposed to asbestos//Chest.- 1999.- №115.- P. 536-549. 


\title{
Варивончик Ав.
}

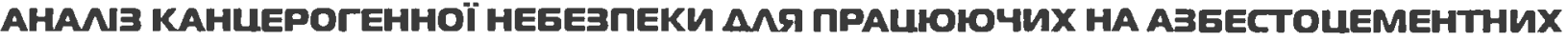 ВИРОБНИUТВАХ (АНАМІТИЧНЕ АОСАИХЕННЯ З ВИКОРИСТАННЯМ МЕТА-АНААІЗУ)}

\author{
Інститут меАишини праші АМН України, м. Київ
}

Дослідженням установлено, шо широкс використання азбестоцементних виробів (покрівельного матеріалу та труб) в Україні обумовлсно іхньою низькою шіною і наявністю корисних тсхнічних харакาсристик, нцо відрізняють їх від аналогінних виробів, зроблених з альтернативних матеріалів. Ризик виникнсния злоякісних новоутворснь ссред працівникіз азбестоцементних виробництв формуеться під впливом волокон азбесту і кристалінного кремнію $\left(\mathrm{SiO}_{2}\right)$, якій міститься у цсмснті. Основними механізмами нсопластичної трансформалії кліток органів-мішенсй, під дісю цикідливих виробничих факторів, $\epsilon: \mathrm{Fe}^{2+}-$ і фагоцитзалежний «оксиданиний стрес" (викликаний волокнами азбесту довжиною > 10 мкм та кристалами $\mathrm{SiO}_{2}-$ кзарц, кристобаліт); прямс ушкодження гсному клітин (во-

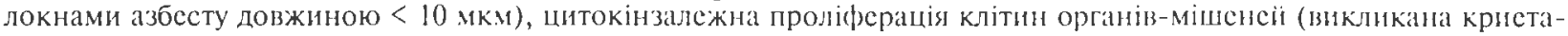
лами $\mathrm{SiO}_{2}$ ). Проведсним кумулятивним мета-аналізом 14 рстроспективних когортних дослілжень смертності працівників азбсстоцсмснтного виробництза за період 1986-20(14 років у Великобританії, США, Швеції, Данії, Італії, Росії, Польші, Литві встановлено пі,двицення відносного ризику смерті від злоякісних новоутворснь (RR=1,94): без урахування виду азбесту - плеври $(\mathrm{RR}=5,37)$, легенів $(\mathrm{R}=1,75)$, товстої і прямої кишки $(\mathrm{RR}=1,51)$, шлунка $(\mathrm{R}=1,22)$, гортані $(\mathrm{RR}=1,01)$. Підвищсний ризик смсртності залсжно від скспозиції працінників різними видами азбссту: хризотил-азбест - загальна смсртність $(\mathrm{RR}=1,23)$, плсври $(\mathrm{RR}=2,90)$, ротоглотки $(\mathrm{RR}=1,83)$, гортані $(\mathrm{R}=1,16)$, товстої і прямої кишки $(\mathrm{RR}=1,16)$; хризотил/крокідоліт/амозит-асбет - загальна смсртність $(R R=1,94)$, плеври $(R R=4,93)$, легень $(R R=2,06)$, тоистої і прямої кишки $(R R=1,83)$, шлунка $(R R=1,31)$, гортані $(R R=1,11)$. Зроблсно висновки про мсншу канцсрогенну нсбезпску при використанні в азбестоцсмснтному виробництві хризотил-азбесту. Рскомсндовано продовжити спідсміологічні досліджсння, спрямовані на аналіз ризикіз, викликаних комбінованим впливом хризотил-азбесту (різного хімічного складу), кристалічним $\mathrm{SiO}_{2}$ (що міститься в цсмснті) та іншими хімічними факторами (барвниками).

Ключові слова: азбестоцементне виробницво, каицерогенна небезпека, азбест, двоокис кремнію, відносний ризик, смертність від злоякісних новоутворень, мета-аналіз

Varvonchyk D.V.

\section{ANALYSIS OF CARCINOGENIC DANGER FOR WORIKERS OF ASBESTOS-CEMENT PRODUCTION (ANALYTICAL STUDY USINC A META-ANALYSIS)}

Institute for Occupational Health of AMS of Ukraine, Kiev

The studies conducted allowed to find out that wide use of asbestos-cement articles (slate roofing, tubes, etc.) in Ukraine is due to their low price and positive technical characteristics that differ them from similar anteles made of alternative materials.

The risk of occurrence of malignant tumors among workers of asbestos-cement enterprises is forming due to fibres of asbestos and crystal silicon $\left(\mathrm{SiO}_{2}\right)$ contained in cement. The main mechanisms of neoplastic transformation of cells, target-organs under the influence of harmful industrial factors are: Fe ${ }^{2+}$ - and phagocyte-dependent "oxidative stress" (caused by asbestos fibres $>10 \mathrm{mcm}$, crystals of $\mathrm{SiO}_{2}$ - quartz, crystobalitc), direct damage of cell genome (by asbestos libres $<10 \mathrm{Mcm}$ ), cytokinedependent cell proliferation of target-organs $\left(\mathrm{SiO}_{2}\right)$.

The used cumulative meta-analysis of 14 retrospective cohort studies on the mortality of workers of asbestos-cement production over the period of 1986-2004 in Great Britain, USA, Sweden, Denmark, Italy, Russian Federation, Poland, Lithuania, allowed to reveal the increase of the relative risk of mortality from malignant tumors (RR-1,94): without account of the type of asbestos - in picura $(R R=5,37)$, lungs $(R R=1,75)$, large intestine and rectum $(R R=1,51)$, stomach $(R R=1,22)$, larynx $(R R=1,01)$. The risk of mortality, depending on the eflect of various types of asbestos, was increased: for chrysotile asbestos - general mortality $(R R=1,23)$, plcura $(R R=2,90)$, mouth and pharynx $(R R=1,83)$, larynx $(R R=1,16)$, large intestine and rectum $(R R=1,16)$; chrysotile/crocidolite/amosite-asbestos - general mortality $(R R=1,94)$, pleura $(R R=4,93)$, lungs $(R R=2,06)$, large intestine and rectum $(R R=1,83)$, stomach $(R R=1,31)$, larynx $(R R=1,11)$.

The conclusions are made on the less carcinogenic danger when using chrysotile asbestos in asbestos-cenent production. It was recommended to continue studies directed to analyzing risks caused by the combined exposure to chrysotile asbestos (of various chemical composition), crystal $\mathrm{SiO}_{2}$ (containing in cement) and other chemical factors (dyes).

Key words: asbestos-cement production, carcinogenic danger, asbestos and crystal silicon, relative risk, mortality from malignant tumors, meta-analysis

Поступила: 05.12 .2006

Контактное лищо: Варивончик Денис Витальевич, старший научный сотрудник отдела эгидемиологических исследований, Институт мсдицины труда АМН Украины, ул. Саксаганского, 75, Кисв (01033, тел.: (044) 289-70-88, c-mail: crzas70@i.com.ua 